\title{
Pengaruh Ketidaksesuaian Hubungan Balok Kolom pada Perencanaan Dengan Pelaksanaan di Lapangan The Effect of Incompatibility of Beam Placement at Colums-End on Design and Application In The Field
}

\author{
Mellisa Indriyani*, Suhendra, M. Nuklirullah \\ Teknik Sipil Universitas Batanghari \\ *Correspondence email: mindriyani36@gmail.com
}

\begin{abstract}
Abstrak. Balok dan kolom dalam perencanaan struktur bangunan gedung bertingkat biasanya digambarkan dengan garis yang memiliki dimensi dan sifat material. Pertemuan balok dan kolom berupa titik yang secara tidak langsung meenggambarkan bahwa pertemuan balok-kolom adalah tepat di sumbu kedua elemen tersebut. Namun pada gambar rencana balok yang dibuat tidak semuanya melalui sumbu kolom. Sehingga terjadi perbedaan besar dan jenis beban dari balok ke kolom. Penelitian ini mengkaji tentang gaya dalam yang timbul akibat ketidaksesuaian desain dengan pelaksanaan lapangan terkait penempatan balok yang tidak tepat di sumbu kolom pada gedung bertingkat. Pertama, gaya dalam dihitung berdasarkan pemodelan pertemuan balok dan kolom adalah tepat di satu titik. Selanjutnya, reaksi tumpuan pada balok yang tidak menumpu pada sumbu kolom dijadikan sebagai momen tambahan pada kolom terkait. Kemudian dilakukan analisis mekanika sekali lagi untuk mendapatkan gaya dalam akibat adanya ketidaktepatan sumbu balok pada sumbu kolom. Gedung yang ditinjau dalam penelitian ini adalah bangunan Rumah Sakit di Kota Jambi, bertingkat lima. Pembebanan dan kriteria analisis menggunakan peraturan yang berlaku di Indonesia. Alat bantu untuk perhitungan gaya dalam menggunakan software SAP2000. Hasil penelitian menunjukkan bahwa terjadi perubahan gaya dalam yang terjadi pada kolom yang memikul balok tidak tepat di sumbunya. Pada kolom bangunan yang ditinjau, gaya dalam mengalami perubahan maksimum menjadi 102,90\% dari gaya dalam tanpa ketidaksesuaian penempatan balok dan minimum menjadi $94,54 \%$.
\end{abstract}

Kata kunci: hubungan balok kolom, momen tambahan, kapasitas kolom

\section{PENDAHULUAN}

Bangunan gedung bertingkat semakin hari semakin banyak di kota Jambi. Hal ini merupakan cara untuk menghemat lahan tanpa mengurangi fungsi dari bangunan gedung tersebut sekaligus berfungsi untuk memajukan perkembangan perkotaan di Kota Jambi.

Dalam perencanaan struktur bangunan gedung bertingkat biasanya digunakan aplikasi seperti SAP 2000, ETABS dan lain-lain. Struktur bangunan atas terdiri balok, kolom dan plat. Balok dan kolom biasanya digambarkan dengan garis yang memiliki kekakuan, panjang dan dimensi. Namun pada gambar rencana balok yang dibuat tidak semuanya melalui sumbu kolom. Sehingga terjadi perbedaan perilaku transfer beban dari balok ke kolom menurut analisis sesuai aplikasi dengan kondisi rill di lapangan.

Untuk itu tujuan yang ingin diperoleh dari penelitian Pengaruh Ketidaksesuaian Hubungan Balok Kolom pada Perencanaan dengan Pelaksanaan di Lapangan ini adalah untuk mengetahui gaya-gaya dalam kolom hasil perencanaan, mengetahui gaya-gaya dalam kolom akibat ketidaksesuain hubungan balok kolom pada perencanaan dengan pelaksanaan di lapangan dan mengetahui perbandingan hasil perencanaan dengan hasil analisis yang sesuai pelaksanaan di lapangan.

Berdasarkan SNI 1727:2013 bangunan gedung adalah struktur yang tertutup oleh dinding dan atap, dibangun untuk melindungi penghuninya. Sedangkan berdasarkan Permen PUPR No.14 Tahun 2017 bangunan gedung adalah wujud fisik hasil pekerjaan konstruksi yang menyatu dengan tempat kedudukannya, sebagian dan/atau seluruhnya berada diatas dan/atau didalam tanah dan/atau air, yang berfungsi sebagai tempat manusia melakukan kegiatannya, baik untuk hunian atau tempat tinggal, tempat keagamaan, kegiatan usaha, kegiatan sosial, budaya maupun kegiatan khusus.

Berdasarkan SNI 2847:2013 Beton Bertulang (Reinforced Concrete) adalah beton struktural yang ditulangi dengan tidak kurang dari jumlah prategang atau tulangan non-prategang minimum. Menurut Dian Ariestadi (2008) beton bertulang adalah beton yang ditulangi dengan luas dan jumlah tulangan yang tidak kurang dari nilai minimum, yang disyaratkan dengan atau tanpa prategang, dan direncanakan berdasarkan asumsi bahwa kedua material bekerja bersama-sama dalam menahan gaya yang bekerja. Sedangkan menurut Ali Asroni (2010) jika kedua bahan (beton dan baja tulangan) dipadukan menjadi satu-kesatuan secara komposit, maka akan diperoleh bahan baru yang disebut beton bertulang. Beton bertulang ini mempunyai sifat sesuai dengan sifat bahan penyusunnya, yaitu sangat kuat terhadap beban tarik maupun beban tekan. Beban tarik pada beton bertulang ditahan oleh baja tulangan, sedangkan beban tekan cukup ditahan oleh beton. 
Menurut Iswandi Imran, dkk (2019) momen terjadi apabila sebuah gaya bekerja mempunyai jarak tertentu dari titik yang akan menahan momen tersebut dan besarnya momen tersebut adalah besarnya gaya dikalikan dengan jaraknya. Satuan untuk momen adalah satuan berat jarak (tm, $\mathrm{kgm}, \mathrm{kgcm}, \mathrm{dsb}$.$) .$

Sedangkan menurut Heinz Frick (1979) hasil gaya kali e (jarak antara garis kerja dan kutub D) ditentukan sebagai momen satu gaya terhadap titik kutub D.

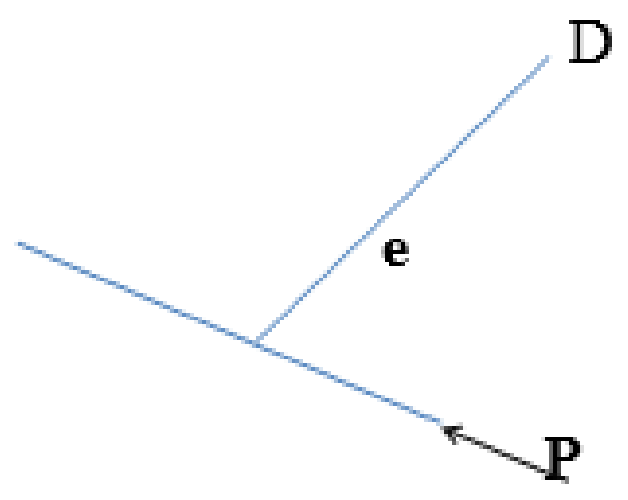

Sumber : Data Olahan, 2020

Gambar 1. Momen

Sehingga momen dapat didefinisikan sebagai $\mathrm{M}=$ P.e, dimana $\mathrm{P}$ (gaya yang bekerja) dan e (eksentrisitas).

\section{Metode Desain Kekuatan}

Menurut Erny Harianti,dkk (2018) struktur dan komponen struktur harus direncanakan sehingga semua penampang mempunyai kuat rencana minimum sama dengan kuat perlu yang dihitung berdasarkan kombinasi beban dan gaya terfaktor.

Kuat rencana adalah kuat nominal dikalikan dengan faktor reduksi $\emptyset$. Kuat nominal adalah kuat komponen struktur atau penampang yang dihitung berdasarkan ketentuan dan asumsi metode perencanaan. Sedangkan kuat perlu adalah kekuatan suatu komponen struktur atau penampang yang diperlukan untuk menahan beban terfaktor yang mencakup dalam kombinasi beban. Dengan kata lain suatu komponen struktur harus memenuhi syarat :

- $\emptyset \mathrm{Pn} \geq \mathrm{Pu}$

- $\emptyset \mathrm{Mn} \geq \mathrm{Mu}$

- $\emptyset \mathrm{Vn} \geq \mathrm{Vu}$

Dimana :

Pn, Mn, Vn adalah kuat nominal gaya aksial, momen dan gaya geser.

$\mathrm{Pu}, \mathrm{Mu}, \mathrm{Vu}$ adalah kuat perlu gaya aksial, momen dan gaya geser.

\section{Hubungan balok dan kolom}

Menurut Ali Asroni (2010) balok dan kolom menjadi satu kesatuan yang kokoh dan sering disebut sebagai kerangka (portal) dari suatu gedung. Portal merupakan kerangka utama dari struktur bangunan, khususnya bangunan gedung. Portal digambarkan dalam bentuk garis-garis horizontal (disebut: balok) dan vertikal (disebut: kolom) yang saling bertemu/berpotongan pada titik buhul (joint).

Menurut Rachmat Purwono (2005) integritas menyeluruh Sistem Rangka Pemikul Momen sangat tergantung pada hubungan balok dan kolom. Degradasi pada hubungan balok dan kolom akan menghasilkan deformasi lateral besar yang dapat menyebabkan kerusakan berlebihan bahkan keruntuhan.

Menurut Eddy Ristanto, dkk (2015) syarat-syarat penting bagi pertemuan balok dan kolom pada struktur beton bertulang antara lain:

a. Harus menunjukan kualitas penampilan dari balok atau kolomnya;

b. Mempunyai kekuatan yang minimal sama dengan kombinasi pembebanan paling berbahaya;

c. Kekuatannya tidak boleh mempengaruhi kekuatan struktur misalnya karena terjadinya degradasi kekuatan;

d. Mudah pelaksanaanya, baik pada pekerjaan pengecoran maupun pada saat pemadatannya. 
Menurut Jati Sunaryati, dkk (2009) eksentrisitas terjadi karena pusat rotasi dengan pusat massa pada gedung tidak berimpit, dengan adanya hal ini mengakibatkan gedung akan mengalami momen torsi yang mengakibatkan gedung mengalami putar, contohnya pada struktur yang tidak beraturan.

Berdasarkan SNI 1727:2013 P - $\Delta$ Effect adalah efek orde kedua pada gaya geser dan momen dari komponen struktur rangka yang ditimbulkan akibat beban aksial pada struktur rangka yang mengalami peralihan lateral.

Sedangkan menurut Rachmat Purwono (2005) semua struktur akibat beban lateral akan melentur kesamping $(\Delta)$. $\Delta$ ini akan menimbulkan momen sekunder (disebut pengaruh $\mathrm{P}-\Delta$ ) oleh beban gravitasi yang titik tangkapnya menyimpang kesamping dengan demikian terjadi beban momen tambahan pada komponen-komponen kolom.

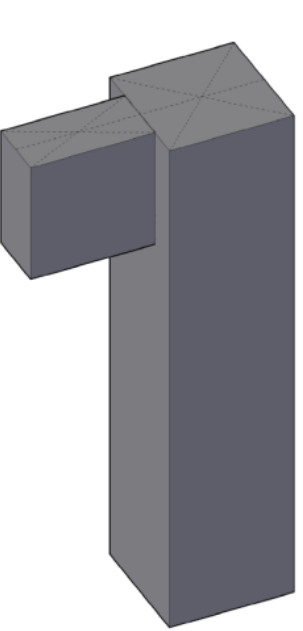

Titik berat balok-kolom sejajar

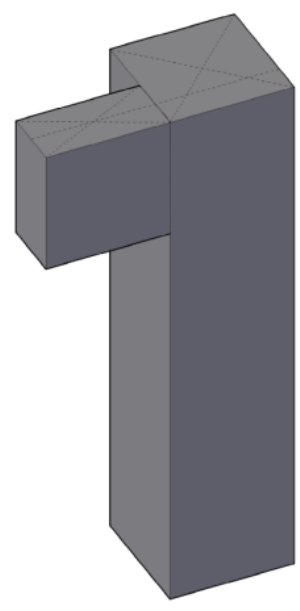

Titik berat balok kolom tidak sejajar

Sumber : Data Olahan, 2020

Gambar 2. Hubungan balok kolom

\section{Pembebanan}

Berdasarkan SNI 1727:2013 beban adalah gaya atau aksi lainnya yang diperoleh dari berat seluruh bahan bangunan, penghuni, barang-barang yang ada didalam bangunan gedung, efek lingkungan, selisih perpindahan dan gaya kekangan akibat perubahan dimensi. Beban-beban yang bekerja pada struktur bangunan gedung antara lain sebagai berikut :

1. Beban Mati (Dead Loads)

Menurut SNI 1727:2013 beban mati adalah berat seluruh bahan bangunan gedung terpasang, termasuk dinding, lantai, atap, plafond, tangga, dinding partisi tetap, finishing, klading gedung dan komponen arsitektural dan struktural lainnya serta peralatan layan terpasang lain termasuk berat keran.

2. Beban Hidup (Live Loads)

Menurut SNI 1727:2013 beban hidup adalah beban yang diakibatkan oleh pengguna dan penghuni bangunan gedung atau struktur lain yang tidak termasuk beban konstruksi dan beban lingkungan seperti beban angin, beban hujan, beban gempa, beban banjir atau beban mati.

3. Beban Gempa ( Earthquake Loads )

Menurut SNI 1726:2012 pengaruh gempa rencana harus ditinjau dalam perencanaan dan evaluasi struktur bangunan gedung serta non gedung serta berbagai bagian dan peralatannya secara umum.

\section{Kombinasi Pembebanan}

Kombinasi pembebanan adalah kekuatan perlu yang dibutuhkan suatu komponen struktur untuk menahan beban terfaktor yang bekerja dengan berbagai kombinasi efek beban tersebut diperlukan kuat perlu (U). Kuat perlu adalah kekuatan suatu komponen struktur atau penampang yang diperlukan untuk menahan beban terfaktor atau momen dengan gaya dalam, faktor keamanan kombinasi pembebanan yang disyaratkan pada SNI 2847:2013. 
Mellisa Indriyani, Suhendra dan Nuklirullah, Pengaruh Ketidaksesuaian Hubungan Balok Kolom pada Perencanaan Dengan Pelaksanaan di Lapangan The Effect of Incompatibility of Beam Placement at Colums-End on Design and Application In The Field

\section{METODE}

\section{Deskripsi Penelitian}

Struktur bangunan gedung bertingkat yang diteliti merupakan konstruksi beton bertulang 5 lantai dengan luas $7955 \mathrm{~m}^{2}$, dimana beberapa balok yang dibuat tidak tepat menumpu di as penampang kolomnya.

\section{Lokasi Penelitian}

Lokasi penelitian adalah Rumah Sakit Bhayangkara Polda Jambi yang beralamat di Jl. Raden Mattaher No.3, Kecamatan Pasar Jambi, Kota Jambi.

\section{Spesifikasi Perhitungan}

Spesifikasi perhitungan meliputi :

1. Fungsi bangunan : Rumah Sakit

2. Struktur bangunan : Beton bertulang

3. Mutu beton : K-350

4. Kolom yang terdiri dari :
a) Kolom K1(Kolom Utama)
: $70 \mathrm{~cm} \times 70 \mathrm{~cm}$
b) Kolom K2(Kolom Pinggir)
: $60 \mathrm{~cm} \times 60 \mathrm{~cm}$
c) Kolom K6 (Kolom Entrance)
: $40 \mathrm{~cm} \mathrm{x} 40 \mathrm{~cm}$

5. Balok yang terdiri dari
a) Balok B1 (Sloof) $\quad: 30 \mathrm{~cm} \mathrm{x} 60 \mathrm{~cm}$
b) Balok B2 (Balok induk) : $35 \mathrm{~cm} \times 70 \mathrm{~cm}$
c) Balok B3 (Balok anak) $\quad: 20 \mathrm{~cm} \mathrm{x} 40 \mathrm{~cm}$

6. Pelat Lantai : Beton bertulang dengan tebal $12 \mathrm{~cm}$

7. Elevasi Lantai

a) Elevasi Lt. Basement $\quad:-2,0 \mathrm{~m}$

b) Elevasi Lt. Dasar : + 1,5 m

c) Elevasi Lt. $1 \quad:+6,0 \mathrm{~m}$

d) Elevasi Lt. $2 \quad:+10,0 \mathrm{~m}$

e) Elevasi Lt. $3 \quad:+14,0 \mathrm{~m}$

f) Elevasi Top Level : $\quad+18,0 \mathrm{~m}$

g) Elevasi Top Roof : $+20,8 \mathrm{~m}$

\section{Metode Perhitungan}

1. Beban

Pembebanan pada perhitungan penelitian ini berpedoman berdasarkan SNI 1727 : 2013 (Beban Minimum Untuk Perancangan Bangunan Gedung dan Struktur Lain).

2. Kombinasi Pembebanan

Kombinasi pada perhitungan penelitian ini berpedoman berdasarkan SNI 2847 : 2013 (Persyaratan Beton Struktural Untuk Bangunan Gedung).

3. Alat Bantu

Alat bantu yang digunakan dalam menganalisa perhitungan pembebanan, gaya-gaya dalam, perhitungan struktur dan lainnya menggunakan bantuan Program SAP 2000 student version dan PCA Column

\section{ANALISIS DAN PEMBAHASAN \\ Modelisasi Struktur}

Untuk menghitung gaya-gaya dalam pada struktur digunakan program SAP 2000 v.14 student version. Pemodelan struktur ini digambarkan dalam bentuk 3 dimensi dimana pelat betonnya dimodelkan sebagai diafragma kaku dan kolom-kolom dianggap terjepit penuh.

Berikut adalah denah lantai bangunan, tipikal. Warna hijau pada gambar merupakan balok yang penempatannya tidak di as kolom. 
Mellisa Indriyani, Suhendra dan Nuklirullah, Pengaruh Ketidaksesuaian Hubungan Balok Kolom pada Perencanaan Dengan Pelaksanaan di Lapangan The Effect of Incompatibility of Beam Placement at Colums-End on Design and Application In The Field
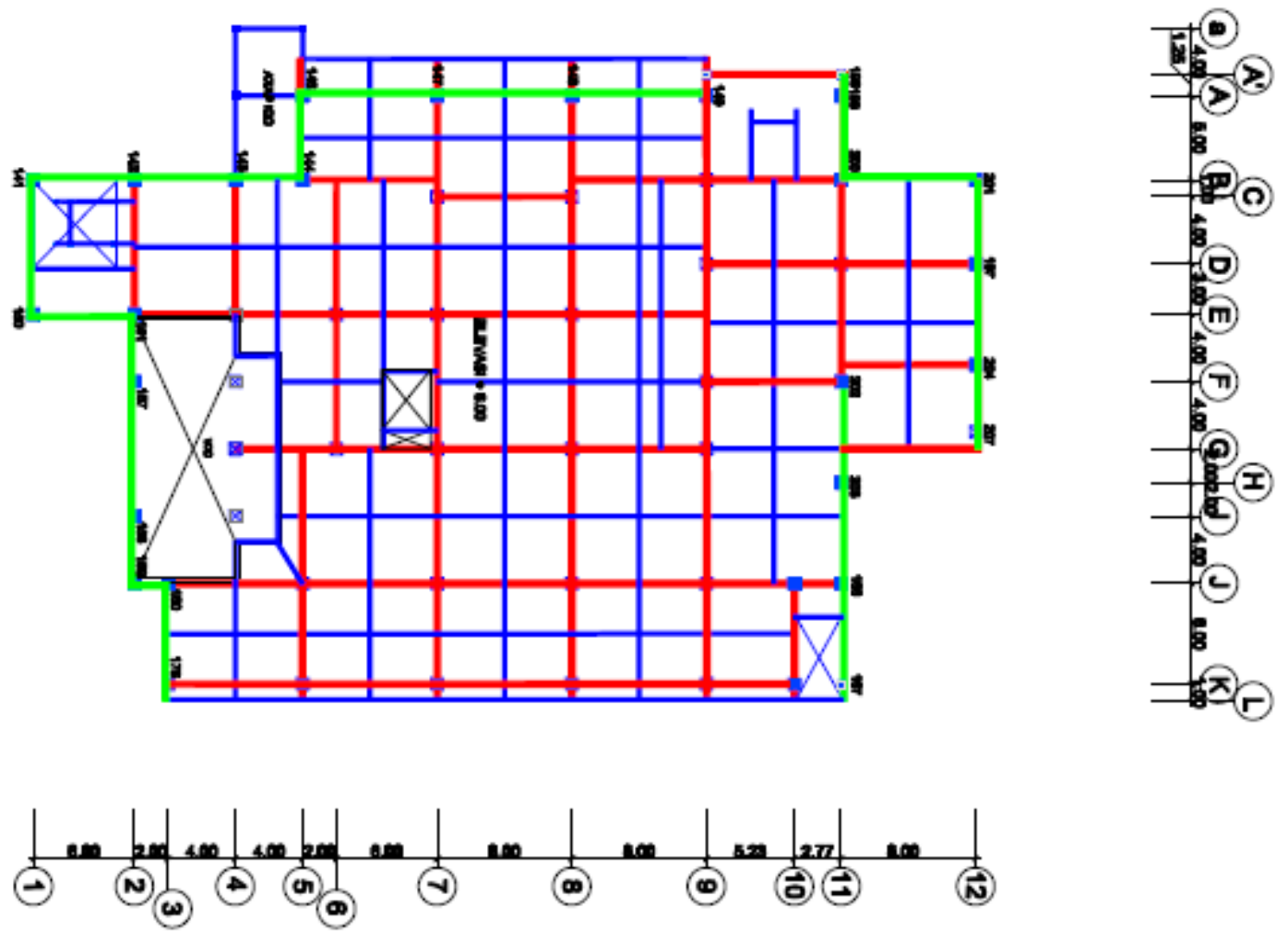

Gambar 3. Denah lantai tipikal

Sumber : Data Olahan, 2020

\section{Perhitungan momen sekunder akibat eksentrisitas}

Pada perencanaan di program SAP 2000 tumpuan balok tepat berada disumbu kolom. Pada beberapa balok yang menumpu tidak di sumbu kolom akan menimbulkan momen tambahan pada kolom tersebut. Momen tambahan tersebut dihitung dengan cara menghitung reaksi perletakan balok yang tidak sentris terhadap kolom terlebih dahulu kemudian dijadikan momen sekunder dengan cara mengalikannya dengan jarak sejauh $e_{x}$ atau $e_{y}$.

Momen sekunder yang telah dihitung selanjutnya dimasukkan ke pemodelan struktur dan dijadikan beban tambahan di joint. Kemudian setelah memasukkan semua beban tambahan pada joint lakukan analisis ulang pada model struktur seperti cara melakukan analisis sebelumnya.

Tabel 1. Hitungan beberapa Momen Sekunder pada kolom

\begin{tabular}{|c|c|c|c|c|c|c|}
\hline $\begin{array}{l}\text { Kolom } \\
\text { Id. }\end{array}$ & $\begin{array}{c}\text { Titik } \\
\text { Kumpul }\end{array}$ & $\begin{array}{l}\text { Balok } \\
\text { Id. }\end{array}$ & $\begin{array}{c}\text { Eksentrisitas } \\
\text { (m) }\end{array}$ & $\begin{array}{l}\text { Reaksi Tumpuan } \\
(\mathrm{kN})\end{array}$ & $\begin{array}{c}\text { Arah } \\
\text { Eksentrisitas }\end{array}$ & $\begin{array}{l}\text { Momen Sekunder } \\
(\mathrm{kNm})\end{array}$ \\
\hline \multicolumn{7}{|c|}{ Lantai Dasar } \\
\hline \multirow{2}{*}{1232} & \multirow{2}{*}{1} & 16 & 0,175 & $-194,85$ & $\mathrm{x}$ & $-34,099$ \\
\hline & & 1 & 0,175 & $-152,37$ & $\mathrm{y}$ & $-26,665$ \\
\hline \multirow{3}{*}{419} & \multirow{3}{*}{68} & 92 & 0,175 & 246,535 & $\mathrm{x}$ & 43,144 \\
\hline & & 93 & 0,175 & $-133,35$ & $\mathrm{x}$ & $-23,337$ \\
\hline & & & & Lantai 1 & & \\
\hline \multirow{2}{*}{163} & \multirow{2}{*}{160} & 498 & 0,175 & 742,73 & $\mathrm{y}$ & 129,978 \\
\hline & & 516 & 0,175 & $-332,03$ & $\mathrm{x}$ & $-58,105$ \\
\hline \multirow{3}{*}{394} & \multirow{3}{*}{203} & 563 & 0,175 & 710,3 & $\mathrm{x}$ & 124,303 \\
\hline & & 564 & 0,175 & $-397,43$ & $\mathrm{x}$ & $-69,55$ \\
\hline & & & & Lantai 2 & & \\
\hline \multirow{2}{*}{1270} & \multirow{2}{*}{295} & 655 & 0,175 & 297,26 & $\mathrm{x}$ & 52,021 \\
\hline & & 656 & 0,175 & $-513,95$ & $\mathrm{y}$ & $-89,942$ \\
\hline \multirow{3}{*}{393} & \multirow{3}{*}{339} & 721 & 0,175 & 700,377 & $\mathrm{x}$ & 122,566 \\
\hline & & 722 & 0,175 & $-373,69$ & $\mathrm{x}$ & $-65,396$ \\
\hline & & & & Lantai 3 & & \\
\hline \multirow{2}{*}{392} & \multirow{2}{*}{475} & 880 & 0,175 & $-350,64$ & $\mathrm{x}$ & $-61,362$ \\
\hline & & 879 & 0,175 & 668,372 & $\mathrm{x}$ & 116,965 \\
\hline
\end{tabular}


Mellisa Indriyani, Suhendra dan Nuklirullah, Pengaruh Ketidaksesuaian Hubungan Balok Kolom pada Perencanaan Dengan Pelaksanaan di Lapangan The Effect of Incompatibility of Beam Placement at Colums-End on Design and Application In The Field

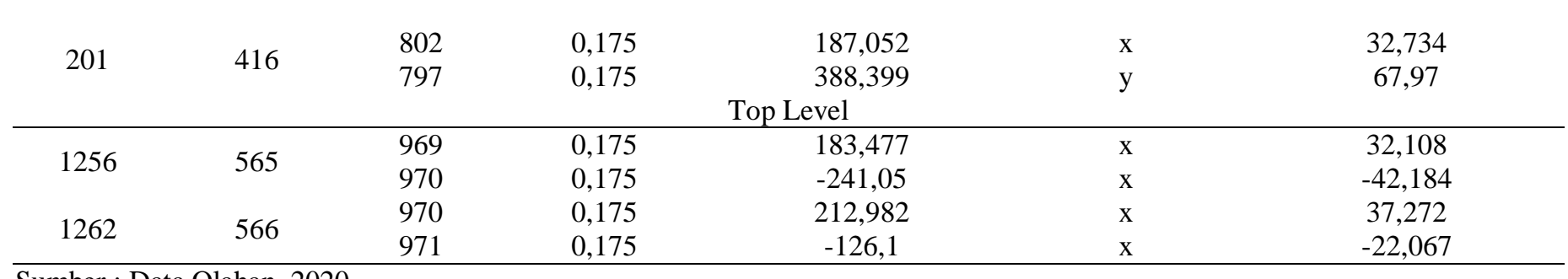

Sumber : Data Olahan, 2020

\section{Perhitungan pengaruh ketidaksesuaian pemasangan balok terhadap titik berat kolom}

Setelah semua proses analisis selesai, keluarkan output gaya-gaya dalam kolom yang titik berat baloknya tidak sentris terhadap titik berat kolom dari proses analisis pertama (yang belum ditambahkan momen sekunder) dan analisis kedua (yang telah ditambahkan momen sekunder). Kemudian gaya-gaya dalam yang bersesuaian pada kedua analisis tersebut dibandingkan.

Gaya-gaya dalam yang dibandingkan merupakan gaya-gaya dalam yang memiliki nilai ekstrim untuk masingmasing tingkat. Hasilnya ditampilkan pada Tabel 2 seperti berikut :

Tabel 2. Perbandingan nilai ekstrim gaya-gaya dalam kolom

\begin{tabular}{|c|c|c|c|c|c|c|}
\hline & $\mathbf{P}$ & $\mathbf{V 2}$ & V3 & $\mathbf{T}$ & M2 & M3 \\
\hline & $\mathrm{KN}$ & $\mathrm{KN}$ & $\mathrm{KN}$ & $\mathrm{KN}-\mathrm{m}$ & $\mathrm{KN}-\mathrm{m}$ & $\mathrm{KN}-\mathrm{m}$ \\
\hline \multicolumn{7}{|c|}{ Kolom Lantai Basement } \\
\hline Awal & $-7808,283$ & $-6214,045$ & $-5649,711$ & 0,000 & 691,843 & 522,173 \\
\hline Sesudah & $-7802,234$ & $-6210,020$ & $-5813,492$ & 0,000 & 693,300 & 523,091 \\
\hline Perubahan & $99,92 \%$ & $99,94 \%$ & $102,90 \%$ & $0,00 \%$ & $100,21 \%$ & $100,18 \%$ \\
\hline \multicolumn{7}{|c|}{ Kolom Lantai Dasar } \\
\hline Awal & $-6330,234$ & $-338,235$ & $-415,882$ & $-7,924$ & $-895,969$ & $-796,888$ \\
\hline Sesudah & $-6334,284$ & $-338,612$ & $-399,618$ & $-8,019$ & $-868,260$ & $-797,804$ \\
\hline Perubahan & $100,06 \%$ & $100,11 \%$ & $96,09 \%$ & $101,19 \%$ & $96,91 \%$ & $100,11 \%$ \\
\hline \multicolumn{7}{|c|}{ Kolom Lantai 1} \\
\hline Awal & $-4650,552$ & 1382,653 & 508,178 & $-9,803$ & 783,805 & $-580,865$ \\
\hline Sesudah & $-4653,576$ & 1359,410 & 517,971 & $-10,087$ & 743,595 & 549,179 \\
\hline Perubahan & $100,07 \%$ & $98,32 \%$ & $101,93 \%$ & $102,90 \%$ & $94,87 \%$ & $94,54 \%$ \\
\hline \multicolumn{7}{|c|}{ Kolom Lantai 2} \\
\hline Awal & $-3030,244$ & $-273,307$ & $-382,892$ & $-7,960$ & 675,779 & $-490,924$ \\
\hline Sesudah & $-3032,495$ & $-275,903$ & $-363,247$ & $-8,044$ & 644,880 & $-498,869$ \\
\hline Perubahan & $100,07 \%$ & $100,95 \%$ & $94,87 \%$ & $101,05 \%$ & $95,43 \%$ & $101,62 \%$ \\
\hline \multicolumn{7}{|c|}{ Kolom Lantai 3} \\
\hline Awal & $-1560,675$ & $-296,953$ & $-371,773$ & $-5,354$ & 700,818 & $-613,093$ \\
\hline Sesudah & $-1563,258$ & $-297,096$ & $-352,892$ & $-5,408$ & 667,668 & $-613,485$ \\
\hline Perubahan & $100,17 \%$ & $100,05 \%$ & $94,92 \%$ & $101,01 \%$ & $95,27 \%$ & $100,06 \%$ \\
\hline
\end{tabular}

Sumber : Data Olahan, 2020

Dari Tabel 2 dapat terlihat bahwa perubahan gaya dalam kolom yang terjadi berkisar antara 94,54\% - 102,90\%.

\section{Diagram interaksi kolom}

Dari hasil analisa gaya-gaya dalam kolom yang titik berat balok yang tidak sentris pada titik berat kolom, maka selanjutnya dapat dilihat diagram interaksi kolom untuk mengetahui kekuatan penampang kolom dapat menahan gaya dalam yang bekerja atau tidak dengan menggunakan program PCA COLUMN v.3.63.

Dari hasil pemeriksaan diagram interaksi kolom didapatkan hasil sebagai berikut :

- Diagram interaksi arah X 
Sumber : Data Olahan, 2020

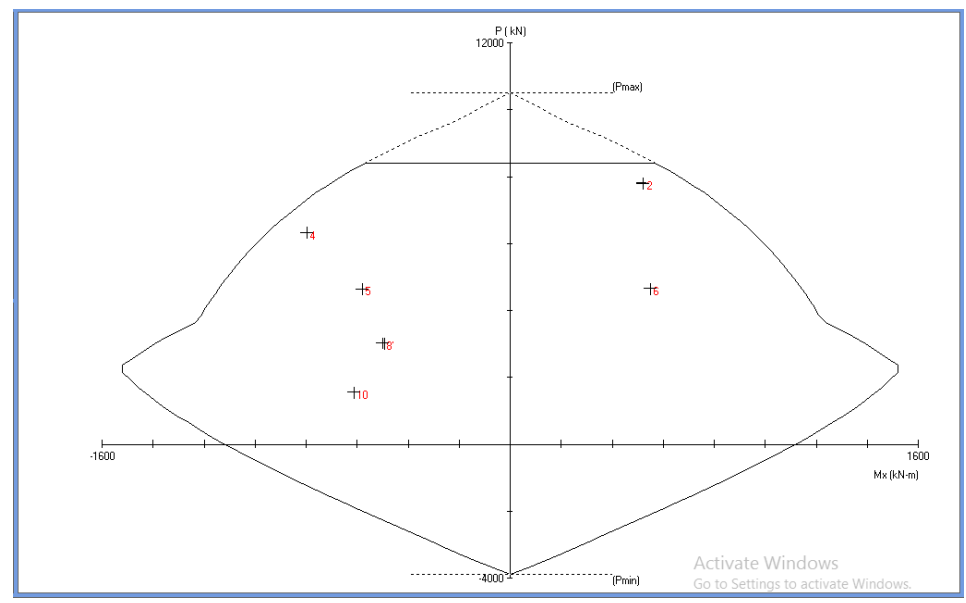

Gambar 4. Diagram interaksi kolom arah X

- Diagram interaksi arah Y

Sumber : Data Olahan, 2020

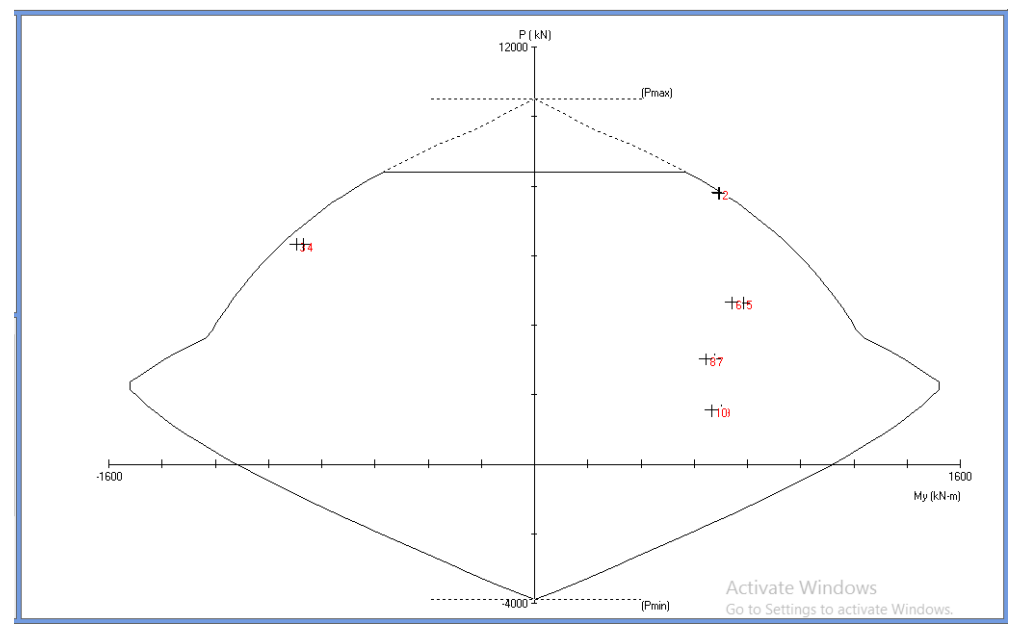

Gambar 5. Diagram interaksi kolom arah Y

Sehingga dapat dilihat bahwa penampang kolom masih cukup aman menahan gaya dalam kolom (P-Mx) pada seluruh lantai, namun untuk gaya dalam kolom (P-My), khususnya pada lantai dasar, gaya dalam yang terjadi hampir mencapai batas kekuatan maksimum kolom.

\section{SIMPULAN}

Adapun kesimpulan yang dapat dirangkum dalam penelitian ini adalah :

1. Hasil analisis struktur bangunan gedung tahan gempa Rumah Sakit Bhayangkara Polda Jambi diperoleh :

a. Faktor keutamaan gempa 1,5 dan kategori resiko IV dengan kategori Desain Seismik (KDS) D sehingga diizinkan untuk menggunakan sistem penahan gaya seismik Sistem Rangka Pemikul Momen Khusus (SRPMK);

b. Periode Ta $<\mathrm{Tc}<\mathrm{Tmax}$, maka digunakan (Tc) periode alami mode 1 .

c. Perbandingan geser dasar statis dan geser dasar dinamis diperoleh $V_{D}<85 \% V_{S}$ untuk arah $\mathrm{X}$ dan arah $\mathrm{Y}$, sehingga perlu diberikan skala gaya pada pemodelan struktur.

2. Berdasarkan hasil analisa struktur setelah diberikan pengaruh momen sekunder akibat beberapa balok yang menumpu tidak tepat di sumbu kolom, didapatkan perbandingan gaya-gaya dalam kolom mengalami perubahan berkisar $94,54 \%-102,90 \%$.

3. Berdasarkan dari hasil pemeriksaan diagram interaksi kolom dapat dilihat bahwa penampang kolom masih cukup aman menahan gaya dalam kolom (P-Mx) pada seluruh lantai, namun untuk gaya dalam kolom (P-My), khususnya pada lantai dasar, gaya dalam yang terjadi hampir mencapai batas kekuatan maksimum kolom. 
Mellisa Indriyani, Suhendra dan Nuklirullah, Pengaruh Ketidaksesuaian Hubungan Balok Kolom pada Perencanaan Dengan Pelaksanaan di Lapangan The Effect of Incompatibility of Beam Placement at Colums-End on Design and Application In The Field

\section{DAFTAR PUSTAKA}

Badan Standarisasi Nasional, 2013. Beban Minimum Untuk Perancangan Bangunan dan Struktur lain (SNI-17272013), Badan Standardisasi Nasional, Jakarta.

Badan Standarisasi Nasional, 2013. Persyaratan Beton Struktural Untuk Bangunan Gedung (SNI-2847-2013), Badan Standardisasi Nasional, Jakarta.

Badan Standarisasi Nasional, 2012. Tata Cara Perencanaan Ketahanan Gempa untuk Struktur Bangunan Gedung dan Non Gedung (SNI-1726-2012), Badan Standardisasi Nasional, Jakarta.

Peraturan Menteri Pekerjaan Umum dan Perumahan Rakyat, 2017. Persyaratan Kemudahan Bangunan Gedung (Permen PUPR No.14 Tahun 2017), Jakarta.

Edward G Nawy, 1998. BETON BERTULANG: Suatu Pendekatan Dasar, PT.Refika Aditama. Bandung

Rachmat Purwono, 2005. Perencanaan Struktur Beton Bertulang Tahan Gempa, ITS Press. Surabaya

Ali Asroni, 2010. Balok dan Pelat Beton Bertulang, Graha Ilmu. Yogyakarta

Ali Asroni, 2010. Kolom, Fondasi dan Balok “T” Beton Bertulang, Graha Ilmu. Yogyakarta

Dian Ariestadi, 2008. Teknik Struktur Bangunan Jilid 3, Direktorat Pembinaan Sekolah Menengah Kejuruan. Jakarta

Eddy Ristanto, Suyadi, Laksmi Irianti, 2015. Analisis Joint Balok Kolom dengan Metode SNI 2847:2013 dan ACI 352R-2002 pada Hotel Serela Lampung, Universitas Lampung. Lampung

Jati Sunaryati, Ruddy Kurniawan, Eko Sukma Putra, 2009. Pengaruh Eksentrisitas Pusat Massa Bangunan Beton Bertulang Terhadap Stabilitas Struktur yang Mengalami Beban Gempa, Universitas Andalas. Sumatera Barat

Heinz Frick, 1979. Mekanika Teknik 1 Statika dan Kegunaannya, Kanisius. Yogyakarta.

Erny Harianti, Anugrah Pamungkas. 2018. Struktur Beton Bertulang Tahan Gempa. Andi Offset. Yogyakarta.

SAP 2000, 1995. Introductory Tutorial for SAP 2000, SAP 2000. California. 